\title{
The Influence of Open Ended Learning Model Mathematical Problem Solving Ability
}

\section{Gesit Puspa Pamungkas ${ }^{1 *}$, Kowiyah ${ }^{2}$}

1,2 PGSD, Universitas Muhammadiyah Prof. Dr. HAMKA, Jakarta, Indonesia

\section{ART ICLE INFO}

\section{Article history:}

Received June 08, 2021

Revised June 11, 2021

Accepted July 23, 2021

Available online August 25, 2021

\section{Kata Kunci:}

Matematika, Pemecahan

Masalah, Open Ended

\section{Keywords:}

Mathematic, Problem Solving, Open Ended

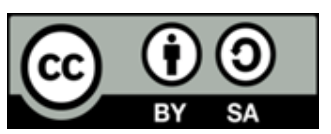

This is an open access article under the CC BY-SA license.

Copyright (c) 2021 by Author. Published by Universitas Pendidikan Ganesha.

\begin{abstract}
A B S T RAK
Permasalahan utama pada penelitian ini adalah rendahnya kemampuan pemecahan masalah matematika siswa sekolah dasar. Kurang efektifnya model pembelajaran yang digunakan oleh guru, menjadi penyebab dari permasalahan tersebut. Tujuan penelitian ini adalah menganalisis model pembelajaran Open Ended terhadap kemampuan pemecahan masalah matematika. Penelitian ini menggunakan pendekatan kuantitatif eksperimen dengan metode Quasi Eksperimen dan desain penelitiannya adalah Post-Test Only Control Design. Subjek penelitian ini adalah siswa kelas IV sebanyak 49 siswa, dengan sampel penelitian terdiri dari dua kelompok, yaitu kelas IVB sebagai kelompok eksperimen sebanyak 24 siswa dan kelas IVD sebagai kelompok kontrol sebanyak 25 siswa. Adapun instrumennya berupa test kemampuan pemecahan masalah matematika berupa esai soal open ended. Hasil penelitian ini menunjukkan terdapat pengaruh model pembelajaran Open Ended terhadap kemampuan pemecahan masalah matematika dengan hasil $t_{\text {hitung }}>t_{\text {tabel }}(37,23>2,01)$. Dengan demikian diperoleh hasil bahwa $\mathrm{H}_{0}$ ditolak dan $\mathrm{H}_{1}$ diterima, yakni terdapat pengaruh model pembelajaran Open Ended terhadap kemampuan pemecahan masalah matematika siswa. Dapat disimpulkan bahwa Model pembelajaran Open Ended ini sangat membantu dalam proses pembelajaran matematika karena dapat membuat siswa lebih aktif selama kegiatan pembelajaran, melatih siswa untuk berani berpendapat, dan mengembangkan berbagai kemampuannya terutama kemampuan pemecahan masalah matematis.
\end{abstract}

\begin{abstract}
A B S T R A C T
The main problem in this research is the standard mathematical problem-solving ability of elementary school students. The ineffectiveness of the learning model used by the teacher is the cause of these problems. The purpose of this study was to analyze the Open-Ended learning model on mathematical problem-solving abilities. This study uses a quantitative experimental approach with the QuasiExperiment method, and the research design is Post-Test Only Control Design. The subjects of this study were 49 students in class IV, with the research sample consisting of two groups, namely class IVB as the experimental group with 24 students and class IVD as the control group as many as 25 students. The instrument is a test of mathematical problem-solving ability in the form of open-ended essay questions. The results of this study indicate an effect of the Open-Ended learning model on mathematical problem-solving abilities with the results of $t$ ccount>t_table $(37.23>2.01)$. Thus, the result is that $\mathrm{H}_{-} 0$ is rejected, and $\mathrm{H}_{-} 1$ is accepted. That is, there is an effect of the Open-Ended learning model on students' mathematical problem-solving abilities. It can be concluded that the OpenEnded learning model is beneficial in the mathematics learning process because it can make students more active during learning activities, train students to dare to have opinions, and develop various abilities, especially mathematical problem-solving abilities.
\end{abstract}

\section{INTRODUCTION}

Mathematics is a basic science related to logic because it can make students practice thinking to solve a problem (Fathollahzadeh et al., 2021; Hidayat \& Sariningsih, 2018). When students are faced with a problem, of course they will think about how the problem can be solved or resolved. Mathematics is said 
to be learning that must be obtained by every student (Kurnia et al., 2019; Wijaya et al., 2019). Because with this mathematics learning students can grow their various abilities. Mathematics is needed for the process of counting and thinking, which of course these two processes are needed by people in solving problems (Brhane et al., 2021; Legesse et al., 2020). Through learning mathematics, it can indirectly make students to be more active in exploring their abilities. The learning process does not always run smoothly. Sometimes there are obstacles that are experienced. For mathematics learning on fourth grade students at SDN Cempaka Baru 01, the problem is the low mathematical problem solving ability of students. This can happen due to several factors. Lack of understanding of concepts can be the cause of low mathematical problem solving abilities. Because understanding the concept is an important foundation to make it easier for students when pursuing learning mathematics (Hartati et al., 2017; Yin et al., 2020). If students do not understand the concept of the material being studied, students will find it difficult to work on the questions that will be given by the teacher.

The monotonous learning process also affects the mathematical problem solving ability of elementary school students (Fung et al., 2020; Swanson et al., 2021). Because the age of elementary school students will be more interested and motivated to learn if they are involved in the learning process (Lai et al., 2019; Lian et al., 2020). So that students' learning resources are not only teachers and books, but themselves can be used as learning resources. Abstract learning media is also one of the factors for the low mathematical problem solving ability of elementary school students (Suryaningtyas, 2017). Elementary school students more easily understand a lesson that is accompanied by examples that exist in their daily lives (O'Keefe et al., 2021; Riyanto \& Gunarhadi, 2017). For example, in the area of perimeter and area of flat shapes, it is better if the teacher gives examples of flat figures using visual aids that can not only be seen by students but can also be held by students. In addition, the application of an inappropriate learning model can also affect the quality of the learning being undertaken and the abilities possessed by students. Therefore, the teacher must be able to choose what learning model will be used in each lesson appropriately. In determining the learning model, you cannot just choose, but you have to pay attention to many things, including looking at the situation and conditions, adjusting the model to be used with the material to be studied, and adjusting the learning model to the characteristics in the class.

With the provision of math problems, students can practice to hone their problem-solving skills to complete the task (Simon \& Cox, 2019; Yiwen, 2020). Therefore, with students learning mathematics, it is the same as students learning to think using their reasoning to make them more creative and active. In learning mathematics, of course, students are trained to get used to solving problems. A process that aims to find a combination of rules that can be used to deal with new situations is also called problem solving (Benavides-Varela et al., 2020; Noviyana, 2018). Because when a student is faced with something new, it is the same as he must go through a series of processes with a unified rule so that he can handle it well. And when students solve the problems contained in math problems, it goes through stages which will then get the right results. The importance of problem solving in learning mathematics, which certainly requires strategies to facilitate it can also make students have a positive character (Seibert, 2020; Triwahyuningtyas et al., 2020; Wijaya et al., 2019). Because to solve a problem of course we need to find the data first, then the data is identified to the stage of making conclusions (Alman, 2017). With students solving a problem, it is the same as going through a series of processes that aim to solve a problem well which of course can be done in various ways.

There are various learning models that can be applied to mathematics learning (Bryant et al., 2020; Hwang et al., 2020). One of them is the Open Ended learning model. During the learning process students are free to use their own way in solving problems, so they can train students in developing problem solving skills (Alman, 2017; Mahmoud et al., 2020). The questions that use this open-ended learning model are an effort to foster students' mathematical problem solving abilities (Rumapea, 2018). The open-ended learning model in carrying out the learning process includes individual goals and desires that are grown and achieved openly (Oliveira et al., 2021; Sholikhah et al., 2018). The open-ended model helps students develop their mindset, and gives them the opportunity to use a variety of ways to solve a problem according to their abilities in mathematics (Hamid et al., 2013; Magelo et al., 2019). Because by using the open-ended learning model, students have many opportunities to be able to actively participate in solving a problem according to their abilities. So that students can also develop their abilities. Moreover, the open-ended learning model also tends to be more appropriate for mathematics learning because it makes students understand the concepts contained in it (Lestari et al., 2019; Noviyana, 2018). Because with the implementation of this open-ended learning model, it is indirectly easier for students to understand mathematics learning. This open-ended learning model makes students more active in participating in learning which can be obtained from their knowledge and experience with more than one process (Hamid et al., 2013; Istiningrum, 2015). This open-ended learning model can convey students' thoughts about how to solve problems and explain how the process is. 
The syntax of the open ended learning model are Presenting Problems, Designing Learning, Observing and Recording Student Responses, Guiding and Directing Students, and Make Conclusions (Jiang et al., 2018; Lestari et al., 2019). When presenting a problem, the learning begins with presenting an open problem to students, which then students carry out understanding activities by expressing what is known and asked, which of course uses their own language (Hafidzah et al., 2019; Mourtgos \& Adams, 2019). Furthermore, when designing learning is the stage where the teacher provides a pattern of learning activities that can stimulate learning activities and guide students to solve a problem. Then proceed with paying attention and recording student responses where when students express the method they use to solve the problem, the teacher records it on the blackboard so that all students know that there are various ways and answers in solving the problem. In the step of guiding and directing students, the teacher gives students the freedom to conduct discussions between students with the guidance of the teacher in explaining how the process of solving the problems he wrote so that the process of how students do it can be known. After the discussion activities, the results obtained are corrected together to form a conclusion that gets several correct answers with various problem-solving techniques, which is the last step in the syntax of the open-ended learning model (Mahuda, 2017; Sholikhah et al., 2018).

Each learning model certainly has its own advantages. Based on the previous description, we can see that the Open Ended learning model has many advantages. Students play a more active role in learning and often express their thoughts (Hafidzah et al., 2019; Mourtgos \& Adams, 2019). Because at the step of applying the open-ended learning model, students express their opinions using their own language. So that students have more opportunities than usual to use their mathematical knowledge and skills. Not only that, students who have low abilities can participate actively in their own way. Because in this openended learning model students are free to explore and be creative (Balan et al., 2019; Jiang et al., 2018). So that students get motivated from within themselves to explain and prove the results they get. In addition, students also get various experiences in order to find something in answering the problem. This is because there are various ways and results in solving a problem. The purpose of this study is to analyze the effect of the Open-Ended learning model on mathematical problem solving abilities.

\section{METHOD}

In the research method there are 2 approaches, namely quantitative and qualitative. A quantitative approach is carried out to test and prove the description of a phenomenon that has been formulated in the form of variables that are proven to be true or not true from the theory that is believed (Zaluchu, 2020). The research used by the researcher is a quantitative experimental approach, with the method used in this study is the Quasi Experiment method. The research design used is Quasi Experiment with posttest-only control design type, which will be applied to the experimental class and control class. This design uses 2 groups, namely the experimental group and the control group. The experimental group is a class that applies the Open Ended learning model, while the control group is a class that does not apply the Open Ended learning model or in other words the learning is like schools in general. The learning activities are carried out by adjusting the current conditions, namely online through the Zoom Meeting application. The purpose of this online class is to break the chain of the spread of the Covid-19 virus. The learning was carried out in two meetings in the experimental group and two meetings in the control class, after which each group was given questions to obtain a post-test of the learning outcomes.

Data is the most important component in research, because with the data researchers can draw conclusions to find out the results of their research. Data collection techniques are the methods used by researchers in obtaining data to be studied. The data collection used should be in accordance with the characteristics of the research to be carried out, in order to facilitate researchers in obtaining the desired data. The data collection technique in this study was in the form of a written test whose material was the circumference and area of a flat shape. The test is through a post test which is carried out at the end of the meeting. Post test was given to each group in order to determine the level of students' problem solving abilities and to obtain research needs. As for the need for scoring guidelines criteria for answers to students' mathematical problem solving ability tests.

Table 1. Score Guidelines in Problem Solving Ability Test

\begin{tabular}{clc}
\hline Rated Aspect & \multicolumn{1}{c}{ Reaction to Problems/Problems } & Score \\
\hline \multirow{2}{*}{$\begin{array}{c}\text { Understanding } \\
\text { problem }\end{array}$} & Incapable to understand the question or no answer & 0 \\
& Not paying attention to the terms of the question or & 1 \\
misinterpreting the question & Understanding the question well & 2 \\
\hline
\end{tabular}




\begin{tabular}{clc}
\hline Rated Aspect & \multicolumn{1}{c}{ Reaction to Problems/Problems } & Score \\
\hline & Inappropriate the planned strategy & 1 \\
& Unfihished using one strategy & 2 \\
& Using one particular strategy but not leading to problem solving & 3 \\
& Using certain strategies but not leading to problem solving & 4 \\
& No solution & 0 \\
& Unclear procedure of solution & 1 \\
& Using one particular procedure and leading to the correct & 2 \\
Solving problem & answer & 3 \\
& Using a certain procedure that is correct but wrong in calculating & 0 \\
& Using certain correct procedures and correct results & 1 \\
& No checking answer & 2 \\
& Checking answer with inaccurate conclusion & Score \\
& Interpret the results obtained by making appropriate & $\mathbf{1 2}$ \\
\hline & conclusions & (Modified from Ima et al., 2020)
\end{tabular}

Before the test questions were used, the researcher carried out a validity test first. Validity test is done by using the Product Moment formula. Next, enter the reliability calculation using the Cronbach Alpha formula. The results obtained from this calculation are $r_{\text {count }}=0.952>r_{\text {table }}=0.361$, and the instrument's problem-solving ability is reliable. Furthermore, data analysis techniques were carried out to conclude whether the application of the Open Ended learning model had an effect on the ability to solve mathematical problems or not. The analysis technique uses the Liliefors test to conclude whether the observed sample distribution comes from a normally distributed population or not. Then, the homogeneity test used Fisher's exact test to determine whether the two groups have homogeneous variance or not. Followed by hypothesis testing using the T test and finally knowing how much influence the learning model has using the Effect Size test formula.

\section{RESULT AND DISCUSSION}

\section{Result}

The results of the research conducted in class IV at SDN Cempaka Baru 01 were obtained by giving a post test given at the end of the study. It aims to determine the level of problem-solving skills possessed by students in the experimental class and control class. The results of the post-test data analysis in the table above state that there are differences in each statistical data. In the experimental class, the highest score was 98 and 90 in the control class. The lowest score for the experimental class is 60 and the control class is 40 . The average value for the experimental class is 78, which is higher than the control class, which is only 65. More values are obtained in the experimental class and the control class, which are different, namely the experimental class mode is 93 and the control class mode is 75 . The difference in the mean in the two classes, namely the experimental class obtained a median of 76 while the control class obtained a median of 63 . The difference in the value of students' mathematical problemsolving abilities is caused by the application of the learning model used in each class. In the application of the Open-Ended learning model students become more active in learning because students can practice to dare to have an opinion. In addition, with the implementation of the Open-Ended learning model, students can develop their abilities both from science and from experience compared to the implementation of conventional models which are less able to make students explore their abilities.

The results of the normality test in the experimental group and the control group were normally distributed. This happened because both groups obtained the results $\mathrm{L}_{\text {count }}<\mathrm{L}_{\text {table }}$. In the experimental group, the $\mathrm{L}_{\text {count }}$ is 0.159 and the $\mathrm{L}_{\text {table }}$ is 0.190 . For the control group, the $\mathrm{L}_{\text {count }}$ is 0.141 and the $\mathrm{L}_{\text {table }}$ is 0.173. Furthermore, the homogeneity test of the two groups was carried out using Fisher's exact test to get a conclusion whether the two sample groups had homogeneous variance or not. The results of the homogeneity test analysis in both groups were homogeneous. This is because $F_{\text {count }}<F_{\text {table }}$. After testing for normality and homogeneity, it can be concluded that the two groups were normally distributed and homogeneous. Furthermore, researchers can analyze the hypothesis test by using the t-test. As for the criteria $\mathrm{H}$ is accepted if $t_{\text {count }}>t_{\text {table }}$, then there is an influence on the ability to solve mathematics by applying the Open-ended learning model. On the other hand, if $t_{\text {count }}>t_{\text {table, }}$, then $\mathrm{H}_{0}$ is rejected, which means that there is no effect on mathematical problem-solving ability with the implementation of the Open-Ended learning model. The results of the analysis of hypothesis testing are obtained that $\mathrm{H}_{1}$ is 
accepted. So it can be concluded that the Open Ended learning model has an influence on mathematical problem solving abilities. To find out how big the effect is, the Effect Size test is calculated. From the calculation results of the Effect Size test, the result is 0.8, which means that the Open-Ended learning model has a high effect on mathematical problem-solving abilities. The following are the criteria for the Effect Size value. The difference in the average value of the post test results can show that there is a difference in the experimental group and the control group. Where the experimental group is superior to the control group. This is because the experimental group applied the Open-Ended learning model, while the control group did not apply it. Learning in both groups was done through the Zoom Meeting application which had been provided by the researcher, with each group carrying out learning in two meetings.

The post test questions were given simultaneously at the end of the meeting with the same questions related to the circumference and area of flat shapes that had been studied at the Zoom Meeting meeting. Post test questions are given in the form of description questions. This is because each question given includes all indicators of problem-solving ability. There are 4 indicators of problem-solving ability, namely: (1) Understanding Problems, (2) Planning Solutions, (3) Solving Problems, and (4) Checking Answers. Judging from the first indicator, namely understanding the problem. Students carry out activities to understand the existing problems by expressing what is known and asked in their own language. Because to solve the problem properly and correctly, the first thing to do is to understand the problem. The second indicator is planning a solution. In this indicator students are trained to think in having a picture of the problem. Students design the steps that will be used to solve the problem. The third indicator is solving the problem. After students make a plan of completion, then the next is to carry out the plan. The activities he does include carrying out calculations as planned, checking whether the steps that have been taken are correct or not, and proving the correctness of the steps. The fourth is to re-check the steps that have been done. The activity consists of checking the results obtained, whether the answer can be found in other ways, and can the answer or method be used to solve other problems. So that students can practice their thinking skills more deeply. Based on the explanation above, it can be seen that applying the Open-Ended learning model has an effect on students' mathematical problem-solving abilities. This can be seen from the results of the calculations in table 7 which obtains $t_{\text {count }}$ of 37,2, while $t_{\text {table }}$ with the provisions of $\mathrm{dk} 47$ at a significance level of $5 \%$ is 2,02 . So it is said that $t_{\text {count }}>t_{\text {table }}$, which means $H_{0}$ is rejected and $\mathrm{H}_{1}$ is accepted.

\section{Discussion}

The ability to solve mathematical problems in students who take lessons using the Open-Ended learning model is superior to students who take lessons without using the Open-Ended learning model. This Open-Ended learning model can make students participate more actively than usual because it provides opportunities for students to develop their knowledge and abilities (Hamid et al., 2013). The open-ended learning model can make students participate in learning and have the opportunity to take full advantage of their mathematical knowledge and skills to develop students' creativity (Alman, 2017; Sholikhah et al., 2018). This is also supported by the opinion which states that the main goal of this open ended is not to obtain results alone, but to emphasize how to get to the results (Balan et al., 2019; Mahmoud et al., 2020; Noviyana, 2018). Because using this open-ended learning model can make students more daring to voice their opinions. This results in a variety of answers to each of the existing problems. In addition, the purpose of applying the open-ended learning model is also to stimulate and develop students' thinking skills in solving existing problems according to their abilities (Oliveira et al., 2021).

Students can develop various abilities by how he solves a problem which is of in accordance with his abilities both from knowledge and experience (Chang \& Lan, 2019; Shiow-Fern et al., 2021). Mathematics often presents a problem that must be solved by students. So that students are required to be able to solve these problems well (Stojanović et al., 2021; Sunismi, 2015). So that by going through this open-ended learning process, it can help students to develop their thinking skills in solving a problem well. This is in line with the opinion which states that through open ended learning, students can develop mathematical thinking skills and also develop their mindset to the maximum (Magelo et al., 2019). This open ended makes students not only find results, but also argue in explaining the process to achieve these results (Hassan et al., 2016; Mahuda, 2017). Because with the learning process that uses this open-ended learning model, students practice to solve problems, express their opinions, and explain how the problemsolving process is in their own way. Therefore, the purpose of the learning model is to make students more active in learning, to train students to have the courage to express their opinions, and to develop their abilities both from science and from experience (Shafie et al., 2010; Tjakradidjaja et al., 2016).

Research that can strengthen the results of this study also states that the application of the right learning model is very important which is recommended in the learning process which can later help 
students in solving mathematical problems (Fauzi et al., 2017). Another study state that students' mathematical representation of visual reality is higher than in the form of description (Kowiyah \& Mulyawati, 2018). Other research findings also state that the Open-Ended learning model is effectively used in learning (Hamid et al., 2013; Oliveira et al., 2021). It can be concluded that the open-ended learning model is feasible to use in the learning process. The implication of this research is that the openended learning model can be used by teachers to improve students' understanding of mathematics.

\section{CONCLUSION}

Based on the results of the research and discussion described above, it can be concluded that the implementation of the Open-Ended learning model has an influence on students' mathematical problem solving abilities on the circumference and area of flat shapes. This Open Ended learning model is very helpful in the mathematics learning process because it can make students more active during learning activities, train students to dare to have opinions, and develop their various abilities, especially mathematical problem solving abilities.

\section{REFERENCES}

Alman. (2017). The Influence of Open-Ended and STAD Method on the Mathematical Problem-Solving Skills in Terms of Learning Achievement. Jurnal Prima Edukasia, 5(2), 112-124. https://doi.org/10.21831/jpe.v5i2.14280.

Balan, L., Yuen, T., \& Mehrtash, M. (2019). Problem-Based Learning Strategy for CAD Software Using FreeChoice and Open-Ended Group Projects. Procedia Manufacturing, 32. https://doi.org/10.1016/j.promfg.2019.02.223.

Benavides-Varela, S., Callegher, C. Z., Fagiolini, B., Leo, I., Altoè, G., \& Lucangeli, D. (2020). Effectiveness of digital-based interventions for children with mathematical learning difficulties: A meta-analysis. Computers \& Education, 157. https://doi.org/10.1016/j.compedu.2020.103953.

Brhane, K. W., Gebru, M. G., \& Ahmad, A. G. (2021). Mathematical model for the dynamics of Savanna ecosystem considering fire disturbances. Journal of Theoretical Biology, 509. https://doi.org/10.1016/j.jtbi.2020.110515.

Bryant, D. P., Bryant, B. R., Dougherty, B., Roberts, G., \& Pfannenstiel, K. H. (2020). Mathematics performance on integers of students with mathematics difficulties. The Journal of Mathematical Behavior, 58. https://doi.org/10.1016/j.jmathb.2020.100776.

Chang, M. M., \& Lan, S. W. (2019). Exploring undergraduate EFL students' perceptions and experiences of a Moodle-based reciprocal teaching application. Open Learning: The Journal of Open, Distance and eLearning. https://doi.org/10.1080/02680513.2019.1708298.

Fathollahzadeh, K., Mardaneh, E., Cigla, M., \& Asad, M. W. A. (2021). A mathematical model for open pit mine production scheduling with Grade Engineering® and stockpiling. International Journal of Mining Science and Technology, 31(4). https://doi.org/10.1016/j.ijmst.2021.03.011.

Fauzi, M. N., Usodo, B., \& Subanti, S. (2017). The Effect Of Make A Match (MAM) Type Model and Bamboo Dance Type Model Through Cooperative Learning on Students Motivation. Suska Journal of Mathematics Education, 3(1), 27-32.

Fung, W. K., Chung, K. K. H., \& Lam, C. B. (2020). Mathematics, executive functioning, and visual-spatial skills in Chinese kindergarten children: Examining the bidirectionality. Journal of Experimental Child Psychology, 199. https://doi.org/10.1016/j.jecp.2020.104923.

Hafidzah, N. A., Azis, Z., \& Irvan, I. (2019). The Effect of Open Ended Approach on Problem Solving Ability and Learning Independence in Students' Mathematics Lessons. Indonesia Journal of Education \& Mathematics Science, 1(2), 105-110. https: //doi.org/10.30596\%2Fijems.v2i1.6176.

Hamid, R., Baharom, S., Taha, M. R., \& Kadaruddin, L. K. (2013). Competition as an Innovative Studentcentered Learning Method for Open-ended Laboratory Work. Procedia - Social and Behavioral Sciences, 10. https://doi.org/10.1016/j.sbspro.2013.10.726.

Hartati, S., Abdullah, I., \& Haji, S. (2017). Pengaruh Kemampuan Pemahaman Konsep, Kemampuan Komunikasi dan Koneksi Terhadap Kemampuan Pemecahan Masalah. MUST: Journal of Mathematics Education, Science and Technology, 2(1), 43. https://doi.org/10.30651/must.v2i1.403.

Hassan, S. R., Rosli, R., \& Zakaria, E. (2016). The Use of i-Think Map and Questioning to Promote HigherOrder Thinking Skills in Mathematics. Creative Education, 07(07), 1069-1078. https: //doi.org/10.4236/ce.2016.77111.

Hidayat, W., \& Sariningsih, R. (2018). Kemampuan Pemecahan Masalah Matematis dan Adversity Quotient Siswa SMP Melalui Pembelajaran Open Ended. Jurnal JNPM Jurnal Nasional Pendidikan 
Matematika), 2(1), 109-118. https://doi.org/10.1016/S0962-8479(96)90008-8.

Hwang, G. J., Wang, S. Y., \& Lai, C. L. (2020). Effects of a social regulation-based online learning framework on students' learning achievements and behaviors in mathematics. Computers and Education, 160, 104031. https://doi.org/10.1016/j.compedu.2020.104031.

Ima, R.-, Subhan Pamungkas, A. S. P., \& Pamungkas Alamsyah, T. (2020). Penggunaan LKS Eksploratif Berkonteks Budaya Banten Terhadap Kemampuan Pemecahan Masalah Matematis Siswa di SD. Jurnal Ilmiah Sekolah Dasar, 4(2), 290. https://doi.org/10.23887/jisd.v4i2.24274.

Istiningrum. (2015). Efektivitas open-Ended Experiential Learning Cases dalam Peningkatan pertimbangan Profesional. Cakrawala Pendidikan, 34(1), 47-57. https://journal.uny.ac.id/index.php/cp/article/view/4175/pdf.

Jiang, Y., Clarke-Midura, J., Keller, B., Baker, R. S., Paquette, L., \& Ocumpaugh, J. (2018). Note-taking and science inquiry in an open-ended learning environment. Contemporary Educational Psychology, 55. https://doi.org/10.1016/j.cedpsych.2018.08.004.

Kowiyah, \& Mulyawati, I. (2018). An analysis of primary school students' representational ability in mathematics based on gender perspective. Journal of Physics: Conference Series, 948(1). https: //doi.org/10.1088/1742-6596/948/1/012016.

Kurnia, V. T., Damayani, A. T., \& Kiswoyo, K. (2019). Keefektifan Model Pembelajaran Number Head Together (NHT) Berbantu Media Puzzle Terhadap Hasil Belajar Matematika. Jurnal Ilmiah Sekolah Dasar, 3(2), 192. https://doi.org/10.23887/jisd.v3i2.17772.

Lai, A. F., Chen, C. H., \& Lee, G. Y. (2019). An augmented reality-based learning approach to enhancing students' science reading performances from the perspective of the cognitive load theory. British Journal of Educational Technology, 50(1), 232-247. https://doi.org/10.1111/bjet.12716.

Legesse, M., Luneta, K., \& Ejigu, T. (2020). Analyzing the effects of mathematical discourse-based instruction on eleventh-grade students' procedural and conceptual understanding of probability and statistics. Studies in Educational Evaluation, 67. https: //doi.org/10.1016/j.stueduc.2020.100918.

Lestari, S. P., Muhandaz, R., \& Risnawati, R. (2019). Pengaruh Penerapan Pendekatan Open-Ended terhadap Kemampuan Berpikir Kreatif Matematis Berdasarkan Kemandirian Belajar Siswa Sekolah Menengah Pertama Negeri 2 Pekanbaru. JURING (Journal for Research in Mathematics Learning) UIN Sultan Syarif Kasim Riau, 2(3), 239-248. https://doi.org/10.24014/juring.v2i2.7504.

Lian, B., Kristiawan, M., Ammelia, D., Primasari, G., Anggung, M., \& Prasetyo, M. (2020). Teachers' Model in Building Students' Character. Journal of Critical Reviews, 7(14), 927-932. https://doi.org/10.31838/jcr.07.14.165.

Magelo, C., Hulukati, E., \& Djakaria, I. (2019). Pengaruh Model Pembelajaran Open-Ended terhadap Kemampuan Berpikir Kreatif Matematik Ditinjau dari Motivasi Belajar. Jambura Journal of Mathematics, 2(1), 15-21. https://doi.org/10.34312/jjom.v2i1.2593.

Mahmoud, A., Hashim, S. S., \& Sunarso, J. (2020). Learning permeability and fluidisation concepts via openended laboratory experiments. Education for Chemical Engineers, 32. https://doi.org/10.1016/j.ece.2020.05.008.

Mahuda, I. (2017). Pembelajaran Kooperatif Co-Op Co-Op Dengan Pendekatan Open-Ended Untuk Meningkatkan Kemampuan Pemecahan Masalah Matematis Siswa Sma. Jurnal Penelitian Dan Pembelajaran Matematika, 10(2), 31-39. https://doi.org/10.30870/jppm.v10i2.2028.

Mourtgos, S. M., \& Adams, I. T. (2019). The rhetoric of de-policing: Evaluating open-ended survey responses from police officers with machine learning-based structural topic modeling. Journal of Criminal Justice, 64. https://doi.org/10.1016/j.jcrimjus.2019.101627.

Noviyana, H. (2018). Pengaruh Model Open Ended Terhadap Kemampuan Pemecahan Masalah Matematis Siswa Smp. JURNAL E-DuMath, 4(2), 1. https://doi.org/10.26638/je.684.2064.

O’Keefe, P. A., Lee, H. Y., \& Chen, P. (2021). Changing Students' Beliefs About Learning Can Unveil Their Potential. Policy Insights from the Behavioral and Brain Sciences, 8(1), 84-91. https: //doi.org/10.1177/2372732220984173.

Oliveira, A. W., Brown, A. O., Zhang, W. S., LeBrun, P., \& Eaton, L. (2021). Fostering creativity in science learning: The potential of open-ended student drawing. Teaching and Teacher Education, 105. https://doi.org/10.1016/j.tate.2021.103416.

Riyanto, W. D., \& Gunarhadi, G. (2017). The Effectiveness of Interactive Multimedia in Mathematic Learning: Utilizing Power Points for Students with Learning Disability. IJPTE: International Journal of Pedagogy and Teacher Education, 1(1), 55-63. https://doi.org/10.20961/ijpte.v1i1.8400.

Rumapea, R. (2018). Pengaruh Model Pembelajaran Kooperatif Tipe Stad dan Pemberian Soal Open Ended 
Terhadap Kemampuan Pemecahan Masalah Siswa Ditinjau dari Kemampuan Awal Matematika. Pendidikan Matematika, 12(1), 1-14.

Seibert, S. A. (2020). Problem-based learning: A strategy to foster generation Z's critical thinking and perseverance. Teaching and Learning in Nursing, 000, 2-5. https://doi.org/10.1016/j.teln.2020.09.002.

Shafie, Shahdan, \& Liew. (2010). Mastery Learning Assessment Model (MLAM) in teaching and learning $\begin{array}{llll}\text { mathematics. Procedia-Social and Behavioral } & \text { Sciences, }\end{array}$ https: //doi.org/10.1016/j.sbspro.2010.12.040.

Shiow-Fern, Dawie, D. D. S. A., Chong, W.-W., \& Jamal, J. A. (2021). Pharmacy student experience, preference, and perceptions of gaming and game-based learning. Currents in Pharmacy Teaching and Learning, 13(5). https://doi.org/10.1016/j.cptl.2021.01.019.

Sholikhah, Z., Kartana, T. J., \& Utami, W. B. (2018). Efektifitas Model Pembelajaran Open-Ended Terhadap Prestasi Belajar Matematika Ditinjau Dari Kreativitas Siswa. JES-MAT (Jurnal Edukasi Dan Sains Matematika), 4(1), 35. https://doi.org/10.25134/jes-mat.v4i1.908.

Simon, L. M., \& Cox, D. C. (2019). The role of prototyping in mathematical design thinking. The Journal of Mathematical Behavior, 56. https://doi.org/10.1016/j.jmathb.2019.100724.

Stojanović, J., Petkovic, D., Alarifi, I. M., Cao, Y., Denic, N., \& Ilic, J. (2021). Application of distance learning in mathematics through adaptive neuro-fuzzy learning method. Computers \& Electrical Engineering, 93. https://doi.org/10.1016/j.compeleceng.2021.107270.

Sunismi. (2015). Developing Guided Discovery Learning Materials Using Mathematics Mobile Learning Application As An Alternative Media For The Students Calculus II. Cakrawala Pendidikan, 34(3), 334-346. https://journal.uny.ac.id/index.php/cp/article/view/7340/pdf.

Suryaningtyas, C. P. (2017). Pengembangan Perangkat Pembelajaran Matematika dengan PMRI untuk Meningkatkan Kemampuan Pemecahan Masalah dan Komunikasi Matematika Developing a Mathematics Learning Kit Using PMRI Approach to Increase Problem Solving Ability and Mathematics Communication. PYTHAGORAS: Jurnal Pendidikan Matematika, 12(2), 200-209.

Swanson, H. L., Arizmendi, G. D., \& Li, J.-T. (2021). Working memory growth predicts mathematical problem-solving growth among emergent bilingual children. Journal of Experimental Child Psychology, 201. https://doi.org/10.1016/j.jecp.2020.104988.

Tjakradidjaja, F. A., Prabandari, Y. S., Prihatiningsih, T. S., \& Harsono, H. (2016). The role of teacher in medical student self-directed learning process. Journal of Education and Learning (EduLearn), 10(1), 78-84. https://doi.org/10.11591/edulearn.v10i1.2992.

Triwahyuningtyas, D., Ningtyas, A. S., \& Rahayu, S. (2020). The problem-based learning e-module of planes using Kvisoft Flipbook Maker for elementary school students. Jurnal Prima Edukasia, 8(2), 199208. https://doi.org/10.21831/jpe.v8i2.34446.

Wijaya, A. P., Mahayukti, G. A., Gita, I. N., \& Parwati, N. N. (2019). Pengaruh strategi Relating, Experiencing, Applying, Cooperating, Transfering berorientasi kearifan lokal terhadap pemecahan masalah dan karakter. Pythagoras: Jurnal Pendidikan Matematika, 14(2), 178-187. https: //doi.org/10.21831/pg.v14i2.25881.

Yin, H., Shi, L., Tam, W. W. Y., \& Lu, G. (2020). Linking university mathematics classroom environments to student achievement: The mediation of mathematics beliefs. Studies in Educational Evaluation, 66. https://doi.org/10.1016/j.stueduc.2020.100905.

Yiwen, Z. (2020). How do we understand mathematical practices in non-mathematical fields? Reflections inspired by cases from 12th and 13th century China. Historia Mathematica, 52. https://doi.org/10.1016/j.hm.2020.04.004.

Zaluchu, S. E. (2020). Strategi Penelitian Kualitatif dan Kuantitatif Di Dalam Penelitian Agama. Evangelikal: Jurnal Teologi Injili Dan Pembinaan Warga Jemaat, 4(1), 28-38. https://doi.org/10.46445/ejti.v4i1.167. 